\title{
Expressivisms, Knowledge and Truth
}

Royal Institute of Philosophy Supplement: 86

Edited by María J. Frápolli 


\section{Royal Institute of Philosophy Supplements}

The Royal Institute of Philosophy Supplements are published twice a year. Institutional subscribers to the journal Philosophy receive the supplements as part of their subscription. The following supplements are available to purchase as books.

\begin{tabular}{|c|c|c|c|}
\hline olume & & & \\
\hline 43 & 1998 & Current Issues in Philosophy of Mind & (ISBN 0521639271 ) \\
\hline 44 & 1999 & German Philosophy since Kant & (ISBN 0521667828) \\
\hline 45 & 1999 & Philosophy and Public Affairs & (ISBN 0521667844) \\
\hline 46 & 2000 & Logic, Cause \& Action & (ISBN 0521785103) \\
\hline 47 & 2000 & $\begin{array}{l}\text { Philosophy, the Good, the True } \\
\text { and the Beautiful }\end{array}$ & (ISBN 0521785111) \\
\hline 48 & 2001 & Philosophy at the New Millennium & (ISBN 0521005086) \\
\hline 49 & 2001 & Naturalism, Evolution and Mind & (ISBN 0521003733) \\
\hline 50 & 2002 & Time, Reality \& Experience & (ISBN 0521529670) \\
\hline 51 & 2002 & Logic, Thought and Language & (ISBN 0521529662) \\
\hline 52 & 2003 & Philosophy and the Emotions & (ISBN 0521537347) \\
\hline 53 & 2003 & Minds and Persons & (ISBN 0521537339) \\
\hline 54 & 2004 & Modern Moral Philosophy & (ISBN 0521603269) \\
\hline 55 & 2004 & Agency and Action & (ISBN 0521603560) \\
\hline 56 & 2005 & Philosophy, Biology and Life & (ISBN 0521678455) \\
\hline 57 & 2005 & The Philosophy of Need & (ISBN 0521678447) \\
\hline 58 & 2006 & Political Philosophy & (ISBN 0521695597) \\
\hline 59 & 2006 & Preferences and Well-Being & (ISBN 0521695589) \\
\hline 60 & 2007 & Narrative and Understanding Persons & (ISBN 9780521714099) \\
\hline 61 & 2007 & Philosophy of Science & (ISBN 9780521718967) \\
\hline 62 & 2008 & Being: Developments in & \\
\hline & & Contemporary Metaphysics & (ISBN 9780521735445) \\
\hline 63 & 2008 & Kant and Philosophy of Science Today & (ISBN 9780521748513) \\
\hline 64 & 2009 & Epistemology & (ISBN 9780521138581) \\
\hline 65 & 2009 & Conceptions of Philosophy & (ISBN 9780521138574) \\
\hline 66 & 2010 & Philosophy as Therapeia & (ISBN 9780521165150) \\
\hline 67 & 2010 & The Metaphysics of Consciousness & (ISBN 9780521173919) \\
\hline 68 & 2011 & Philosophy and Religion & (ISBN 9781107615984) \\
\hline 69 & 2011 & Philosophy and the Environment & (ISBN 9781107696075) \\
\hline 70 & 2012 & Human Nature & (ISBN 9781107651975) \\
\hline 71 & 2012 & Philosophy and the Arts & (ISBN 9781107661745) \\
\hline 72 & 2013 & Phenomenology and Naturalism & (ISBN 9781107699052) \\
\hline 73 & 2013 & Philosophy and Sport & (ISBN 9781107647695) \\
\hline 74 & 2014 & Philosophical Traditions & (ISBN 9781107434486) \\
\hline 75 & 2014 & Philosophical Aesthetics and & (4587) \\
\hline 76 & 2015 & Mind, Self and Person & (ISBN 9781107545663) \\
\hline 77 & 2015 & Supererogation & (ISBN 9781107545731) \\
\hline 78 & 2016 & History of Philosophy & (ISBN 9781316626269) \\
\hline 79 & 2016 & Philosophy and Museums: Essays & (ISBN 9781107545670) \\
\hline 80 & 2017 & Philosophy of Action & (ISBN 9781108414890) \\
\hline 81 & 2017 & Religious Epistemology & (ISBN 9781108453257) \\
\hline 82 & 2018 & Metaphysics & (ISBN 9781108740623) \\
\hline 83 & 2018 & Moral Enhancement: Critical & \\
\hline & & Perspectives & (ISBN 9781108717342) \\
\hline 8 & 2018 & Harms and Wrongs in Epistem & (ISBN 9781108712 \\
\hline & 2019 & Passions and the Emotions & (ISBN 97811087480 \\
\hline
\end{tabular}

From Volume 13 onwards the Series is published by Cambridge University Press and some earlier titles are also available.

This journal issue has been printed on FSC-certified paper and cover board. FSC is an independent, non-governmental, not-for-profit organization established to promote the responsible management of the world's forests. Please see www.fsc.org for information. 


\section{Expressivisms,}

\section{Knowledge and Truth}

ROYAL INSTITUTE OF PHILOSOPHY SUPPLEMENT: 86

EDITED BY

María J. Frápolli 
PUBLISHED BY THE PRESS SYNDICATE OF THE UNIVERSITY OF CAMBRIDGE

The Pitt Building, Trumpington Street, Cambridge, CB2 1RP, United Kingdom

CAMBRIDGE UNIVERSITY PRESS

UPH, Shaftesbury Road, Cambridge CB2 8BS, United Kingdom

32 Avenue of the Americas, New York, NY 10013-2473, USA

477 Williamstown Road, Port Melbourne, VIC 3207, Australia

C/Orense, 4, planta 13, 28020 Madrid, Spain

Lower Ground Floor, Nautica Building, The Water Club, Beach Road, Granger Bay, 8005 Cape Town, South Africa

(C) The Royal Institute of Philosophy and the contributors 2019

Printed in the United Kingdom at Bell and Bain Ltd.

Typeset by Techset Composition Ltd, Salisbury, UK

A catalogue record for this book is available from the British Library

ISBN 9781108818636

ISSN 1358-2461 


\section{Contents}

Notes on the Contributors $\quad$ v

Introduction: Expressivisms, Knowledge and Truth 1 M. J. FRÁPOLLI

Neo-Expressivism: (Self-)Knowledge, Meaning, and Truth 11 DORIT BAR-ON

Logical Expressivism and Carroll's Regress 35 CORINE BESSON

What Is a Theory of Normative Concepts For? 63 MATTHEW CHRISMAN

$\begin{array}{ll}\text { Propositions First: Biting Geach’s Bullet } & 87\end{array}$ M. J. FRÁPOLLI

Expressivism and Crossed Disagreements JAVIER OSORIO AND NEFTALI VILLANUEVA

Global Expressivism by the Method of Differences HUW PRICE

On Linguistic Evidence for Expressivism ANDRÉS SORIA RUIZ AND ISIDORA STOJANOVIC

The Primacy of Practice JOSÉ L. ZALABARDO

Index of Names 